Endocrinol. Jap., Vol. 1, No. 1 (1954).

\title{
NEUROSEGRETION IN RELATION TO SURGICAL OPERATIONS
}

\author{
KISHUO SHIBUSAWA, TUNAMASA INOU, SHIGEOMI OSONO \\ AND TUYOSHI TOSHIMA
}

\author{
2nd Surgical Department, Faculty of Medicine, Tokyo University, Tokyo
}

\section{NINE FIGURES}

As we have reported previously (Shibusawa and Ino, 1951; Shibusawa, Inou and Itou, 1952; Shibusawa, Inou and Osono, 1953; Shibusawa, Inou, Osono and Yoshimura, 1953; Shibusawa, in press) the antidiuretic substance was proved to be released from the hypothalamus and the posterior pituitary for a short period following surgery. This phenomenon of postoperative neurosecretion occurs not only in a number of experimental animals, but also in man.

The present experiments were undertaken to clarify the secretory mechanism of the hypothalamo-neurohypophyseal system.

\section{MATERIALS AND METHODS}

Fifty mongrel dogs weighing $10 \sim 15 \mathrm{~kg}$. were employed as subjects under the Nembutal Sodium anesthesia. Females were used because of the greater ease of catheterization. The kinds of stressors used were two types, a single laparotomy and a second grade burn in the lower limbs.

Measurement of antidiuretic substance $(A D S)$ : Inou's modification of the original method of Lloyd and Lobotsky (1950). Serum specimen of $0.5 \mathrm{cc}$. was injected into the peritoneal cavity of male rats weighing $100 \sim 150 \mathrm{gm}$. and urine was collected during the 30 minutes after the injection, measured, and compared with that of the control. The antidiuretic activity of the extract of the posterior pituitary (diluted with water to $5 \mathrm{mg} . / \mathrm{ml}$.) and of the extract of the hypothalamus $(100 \mathrm{mg} . / \mathrm{ml}$.) was determined in the same way as the serum specimen.

Kymographic determination of the action current of the vagus and sympathetic nerves: Vagus and sympathetic nerves of the cervical region were exposed and isolated in the Nembutal anesthetized cat, and the action currents of each nerve were induced from the proximal end.

Determination of acetylcholine concentration: Kymographic method by sinus-atrium preparation of the toad heart.

Staining of ganglion cells of hypothalamus and neurohypophysis: Bargmann's modification of Gomori's chromium hematoxylin-phloxin staining (1949).

Determination of nucleic acid: By Schneider's method (1946). Three fractions of phosphorus compounds were extracted quantitatively, and the total phosphorus of each fraction was measured by Allen's colorimetric method (1940). Ribonucleic acid (RNA) was determined by the orcinol-HCl reaction, and desoxyribonucleic acid (DNA) by the diphenylamine reaction.

Received for publication May 30, 1954. 
The experiments were carried out with the following four groups.

1) Single laparotomy or burn (simple stressor or untreated group)

2) Vagotomy of both sides in the cervical region performed 24 hours betore exposure to stressors (vagotomy group)

3) Injection of adrenalin hydrochloride into the carotid artery 30 minutes before exposure to stressors (adrenalin injection group)

4) Subcutaneous injection of atropine sulfate 30 minutes before exposure to stressors (atropine injection group)

\section{RESULTS}

I) The ADS levels in the serum, hypothalamus and posterior pituitary.

a) Simple stressor group: In the normal dog the serum ADS level is -0.56 atonin $U$. and the ADS concentration of the posterior pituitary and hypothalamus extract is about +0.92 atonin U. (Inou, 1952.). The neurosecretory substance of the nerve cells of the nucleus supraopticus is shown abundantly as Gomori's substance by histological observation. This substance is dotted, granulated, striped, or massive in the cell. These substances of the nucleus paraventricularis and posterior pituitary show similar findings.

After the surgical stress the level of the serum ADS becomes higher rapidly and the ADS concentration of the posterior pituitary and hypothalamus decreases conversely. The elevation of the serum level and the depletion of ADS of the posterior pituitary and hypothalamus reach the maximum 4 hours after the stress. In the same period Gomori's substance of the nucleus supraopticus, nucleus paraventricularis, and posterior pituitary are reduced remarkably and disappear completely from the axon plasma. Such biochemical and histological changes are the same in the human as in the experimental animals.

About $13 \%$ of the total amount of the ADH secreted are believed to be excreted in the urine (Heller, 1951; Larson, 1938; O'conner, 1947). According to Vigneaud and his coworkers (1953) ADH is a polypeptide consisting of eight amino acids. When the urine excreted after the stress is developed by the paper chromatography, the polypeptide fraction stained with ninhydrin shows marked antidiuretic activity. 'Therefore, after an intense surgical stress Gomori's substance disappears entirely from the hypothalamus and posterior pituitary, and the distribution of Nissl's substances in the ganglion cells of the nucleus supraopticus becomes uneven. The turnover of the isotopic phosphorus $\left(\mathrm{P}^{32}\right)$ of the nucleic acids and phospholipids in the hypothalamus becomes accelerated after 12 24 hours.

b) Adrenalin injection group: The serum ADS level does not increase, and the ADS concentration of the hypothalamus and the posterior pituitary does not decrease markedly by the surgical stress in this group. Gomori's substance is not reduced morphologically.

c) Atropine injection group: The serum ADS level rises less markedly than in the control, and the ADS concentration of the hypothalamus and the posterior pituitary shows a moderate decrease by the surgical stress in this group. Histologically, Gomori's substance also decreases to a fair extent but not to that of 


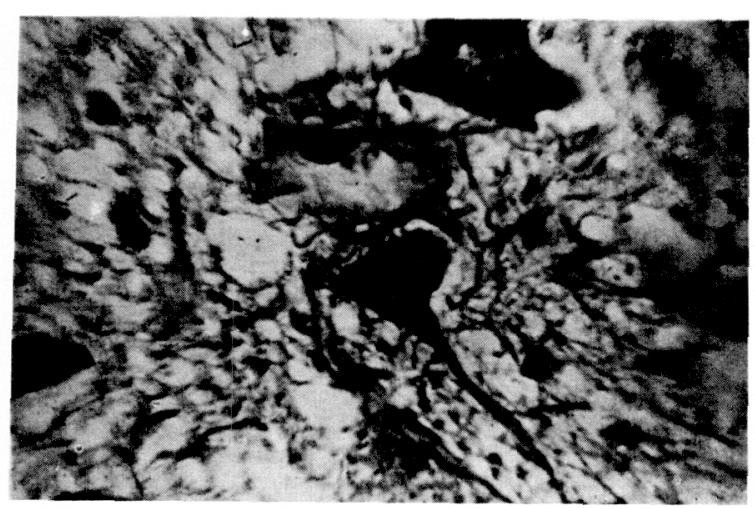

Fig. 1.

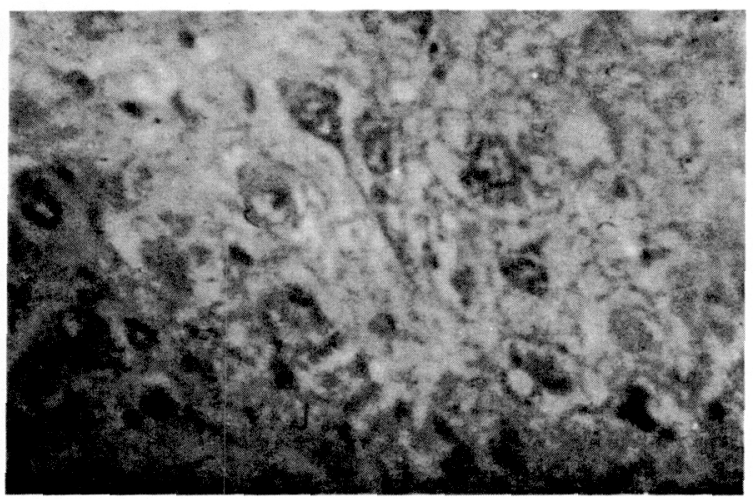

Fig. 2.

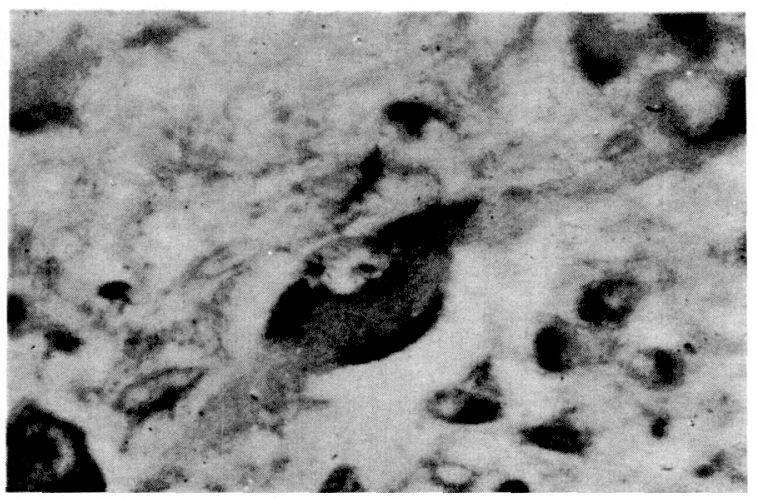

Fig. 3.
The Gomori's substance of the nerve cells in the nucleus supraopticus of the dog. Fig. 1, before the stress. Fig. 2, 4 hours after the stress. Fig. 3, in man dying with a hepato-renal syndrome ( 24 hours after laparotomy). 


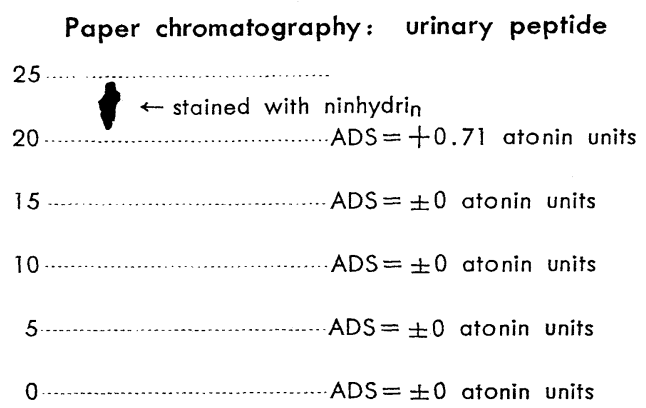

Table 1. Metabolism of acid soluble-P, lipidic-P and nucleic acid $P$ in the hypophysis, hypothalamus and adrenals

\begin{tabular}{|c|c|c|c|c|c|c|c|}
\hline & & \multicolumn{2}{|c|}{ After 4 hours } & \multicolumn{2}{|c|}{ After 12 hours } & \multicolumn{2}{|c|}{ After 24 hours } \\
\hline & & Control & Burn & Control & Burn & Control & Burn \\
\hline Acid soluble-P & $\begin{array}{l}\text { Hypophysis } \\
\text { Hypothalamus } \\
\text { Adrenals }\end{array}$ & $\begin{array}{r}166.99 \\
67.62\end{array}$ & $\begin{array}{r}641.25 \\
3.44\end{array}$ & $\begin{array}{r}25.58 \\
3.70 \\
4.26\end{array}$ & $\begin{array}{r}211.63 \\
81.46 \\
92.21\end{array}$ & $\begin{array}{r}181.13 \\
33.15\end{array}$ & $\begin{array}{r}698.41 \\
96.57\end{array}$ \\
\hline Lipidic-P & $\begin{array}{l}\text { Hypophysis } \\
\text { Hypothalamus } \\
\text { Adrenals }\end{array}$ & $\begin{array}{l}80.58 \\
10.71\end{array}$ & $\begin{array}{r}412.50 \\
6.40\end{array}$ & $\begin{array}{r}25.58 \\
1.34 \\
0.57\end{array}$ & $\begin{array}{r}269.77 \\
2.62 \\
2.25\end{array}$ & $\begin{array}{r}64.15 \\
1.69\end{array}$ & $\begin{array}{r}101.59 \\
9.03\end{array}$ \\
\hline Nucleic acid-P & $\begin{array}{l}\text { Hypophysis } \\
\text { Hypothalamus } \\
\text { Adrenals }\end{array}$ & $\begin{array}{l}88.35 \\
10.43\end{array}$ & $\begin{array}{l}4.17 \\
1.97\end{array}$ & $\begin{array}{c}60.47 \\
1.79 \\
2.90\end{array}$ & $\begin{array}{c}120.93 \\
33.60 \\
78.48\end{array}$ & $\begin{array}{r}156.60 \\
27.53\end{array}$ & $\begin{array}{r}215.87 \\
71.18\end{array}$ \\
\hline DNA & $\begin{array}{l}\text { Hypophysis } \\
\text { Hypothalamus } \\
\text { Adrenals }\end{array}$ & $\begin{array}{r}1520.37 \\
203.09\end{array}$ & $\begin{array}{r}1104.17 \\
196.80\end{array}$ & $\begin{array}{r}1011.63 \\
159.44 \\
827.27\end{array}$ & $\begin{array}{c}1225.00 \\
218.17 \\
671.11\end{array}$ & $\begin{array}{r}1852.09 \\
131.87\end{array}$ & $\begin{array}{r}1269.84 \\
135.51\end{array}$ \\
\hline RNA & $\begin{array}{l}\text { Hypophysis } \\
\text { Hypothalamus } \\
\text { Adrenals }\end{array}$ & $\begin{array}{r}95.44 \\
320.41\end{array}$ & $\begin{array}{r}2916.67 \\
664.21\end{array}$ & $\begin{array}{r}1627.91 \\
510.20 \\
887.78\end{array}$ & $\begin{array}{l}1822.92 \\
1006.55 \\
2448.82\end{array}$ & $\begin{array}{r}1451.27 \\
213.48\end{array}$ & $\begin{array}{r}1390.48 \\
135.70\end{array}$ \\
\hline
\end{tabular}

the untreated group.

d) Vagotomy group: The serum ADS level does not increase, and the ADS concentration of the hypothalamus and the posterior pituitary changes scarcely by the stress. Histologically, Gomori's substance is practically unchanged.

II) Action current of vagus nerve in surgical stress.

Moreover, it is found that the action current of the vagus nerve in the cat is markedly intensified immediately after the surgical stress, and this condition continues for about 10 minutes, but the action current of the sympathetic nerves in the cat is not intensified during this period.

III) Release of acetylcholine in the hypothalamus and posterior pituitary in surgical stress.

Pickford and Watt (1951) found that the secretion of ADH increases with the injection of acetylcholine into the carotid artery. However, by the usual stress, except the surgical shock, acetylcholine can not be found in the blood of the carotid artery. On the contrary, the posterior pituitary shows a very high concentration of acetylcholine and this level reaches its maximum immediately after the stress. In the normal dog killed by an electric shock in $1 \sim 2$ minutes, the acetylcholine concentration is very high in the neurohypophysis, but such cannot 
Table 2. The effect of adrenaline

The ADS levels in the serum

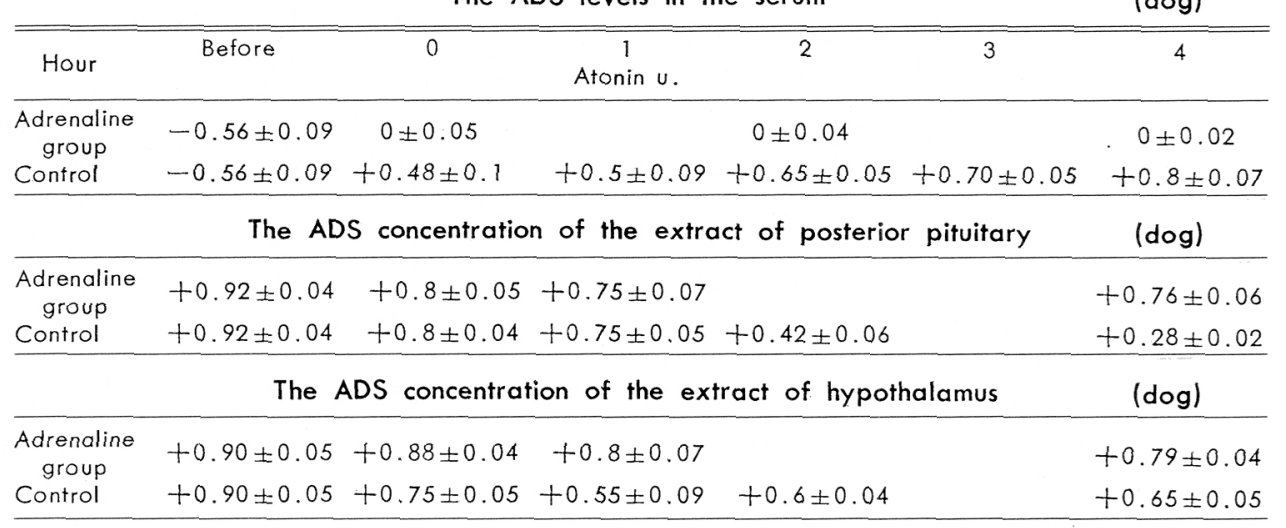

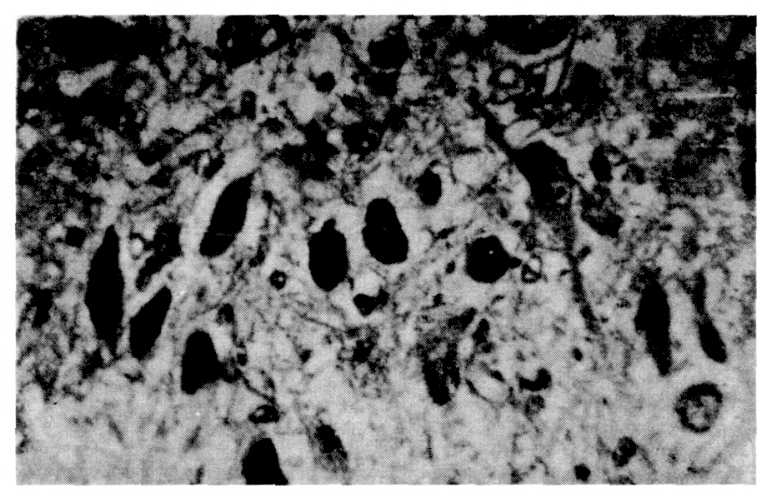

Fig. 4. The Gomori's substance of the nerve cells of nucleus supraopticus in dog of adrenaline injection group (after the stress).

Table 3. The effect of atropine

The ADS levels in the serum

\begin{tabular}{|c|c|c|c|c|c|c|}
\hline Hour & Before & 0 & $\begin{array}{c}1 \\
\text { Atonin-u. }\end{array}$ & 2 & 3 & 4 \\
\hline $\begin{array}{l}\text { Atropine } \\
\text { group }\end{array}$ & $-0.56 \pm 0.09$ & $+0.11 \pm 0.06$ & & $+0.25 \pm 0.05$ & & $+0.44 \pm 0.07$ \\
\hline \multirow[t]{2}{*}{ Control } & $-0.56 \pm 0.09$ & $+0.48 \pm 0.1$ & $+0.5 \pm 0.09$ & $+0.65 \pm 0.05$ & $+0.7 \pm 0.05$ & $+0.8 \pm 0.07$ \\
\hline & The & ADS concentrati & on of the extr & act of posterior & pituitary & (dog) \\
\hline $\begin{array}{l}\text { Atropine } \\
\text { group }\end{array}$ & $+0.92 \pm 0.04$ & $+0.88 \pm 0.06$ & & $+0.75 \pm 0.07$ & & $+0.62 \pm 0.05$ \\
\hline \multirow[t]{2}{*}{ Control } & $+0.92 \pm 0.04$ & $+0.84 \pm 0.04$ & $+0.75 \pm 0.05$ & $+0.42 \pm 0.06$ & & $+0.28 \pm 0.02$ \\
\hline & The & e ADS concentr & ation of the ex & xtract of hypoth & halamus & $(\mathrm{dog})$ \\
\hline $\begin{array}{l}\text { Atropine } \\
\text { group }\end{array}$ & $+0.90 \pm 0.05$ & $+0.86 \pm 0.04$ & & $+0.77 \pm 0.03$ & & $+0.7 \pm 0.05$ \\
\hline Control & $+0.90 \pm 0.05$ & $+0.75 \pm 0.05$ & $+0.55 \pm 0.09$ & $+0.6 \pm 0.04$ & & $+0.65 \pm 0.05$ \\
\hline
\end{tabular}




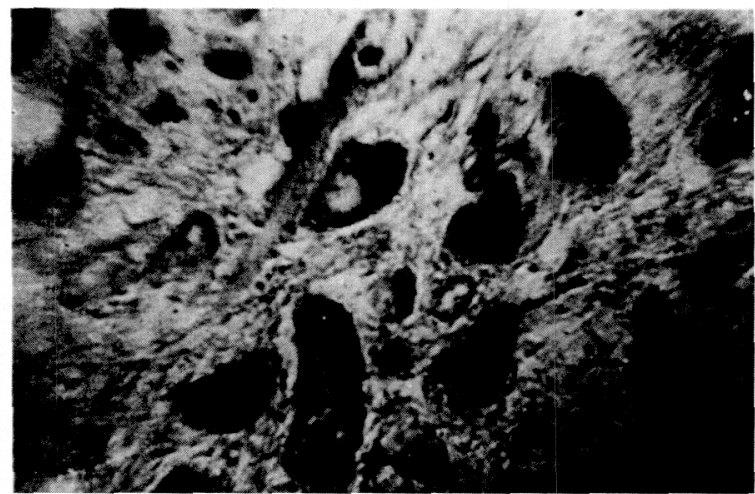

Fig. 5. The Gomori's substance of the nerve cells of nucleus supraopticus in the dog of atropine injection group (after the stress).

Table 4. The effect of vagotomy

The ADS levels in the serum (dog)

\begin{tabular}{|c|c|c|c|c|c|c|}
\hline Hour & Before & 0 & $\begin{array}{c}1 \\
\text { Atonin } u .\end{array}$ & 2 & 3 & 4 \\
\hline $\begin{array}{l}\text { Vagotomy } \\
\text { group }\end{array}$ & $-0.56 \pm 0.09$ & $-0.05 \pm 0.04$ & $0 \pm 0.04$ & $0 \pm 0.05$ & $+0.01 \pm 0.06$ & $+0.04 \pm 0.01$ \\
\hline Control & $-0.56 \pm 0.09$ & $+0.48 \pm 0.1$ & $+0.5 \pm 0.09$ & $+0.65 \pm 0.05$ & $+0.70 \pm 0.05$ & $+0.8 \pm 0.07$ \\
\hline
\end{tabular}

\begin{tabular}{ccc} 
The ADS concentration of the posterior pifuitary & (dog) \\
$\begin{array}{l}\text { Vagotomy } \\
\text { group }\end{array}+0.92 \pm 0.04+0.9 \pm 0.05$ & $+0.9 \pm 0.07$ & $+0.83 \pm 0.06$ \\
Control $+0.92 \pm 0.04+0.84 \pm 0.04+0.75 \pm 0.05+6.42 \pm 0.06$ & $+0.28 \pm 0.02$ \\
\hline The ADS concentration of the hypothalamus & (dog) \\
\hline $\begin{array}{c}\text { Vagotomy } \\
\text { group }\end{array} \quad+0.90 \pm 0.05+0.85 \pm 0.06$ & $+0.8 \pm 0.04$ & $+0.77 \pm 0.04$ \\
Control & $+0.90 \pm 0.05+0.75 \pm 0.05+0.55 \pm 0.09+0.6 \pm 0.04$ & $+0.65 \pm 0.05$ \\
\hline
\end{tabular}

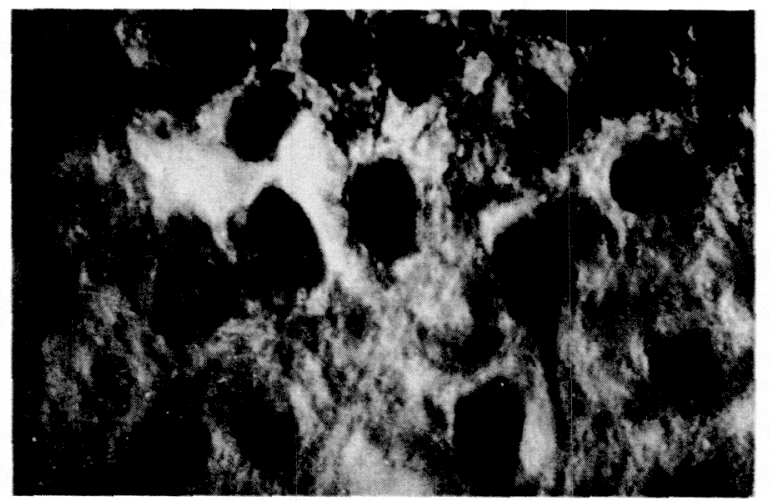

Fig. 6. The Gomori's substance of the nerve cells of nucleus supraopticus in the dog of vagotomy group (after the stress). 
The action current of nerve (cat)

a)

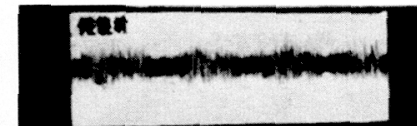

b)

c)

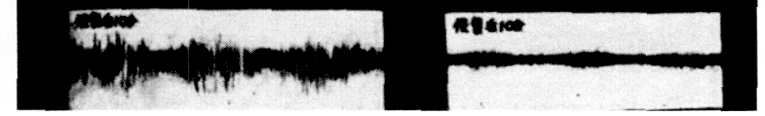

a) Before the stress

b) Immediately after the stress

c) 10 minutes after the stress

Fig. 7. The action current of vagus nerve. (cat)

The action current of nerve (cat)

a)

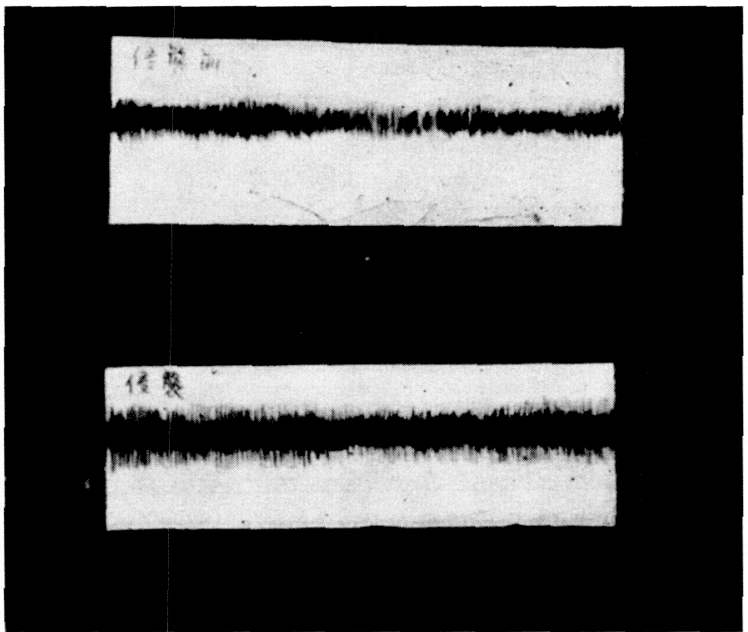

a) Before the stress.

b) Immediately after the stress

Fig. 8. The action current of the sympathetic nerve.(cat)

be found in the hypothalamus. During stress acetylcholine is believed to be released from the neurohypophysis, but not from the hypothalamus. The level of the acetylcholine of the hypothalamus increases gradually thereafter. On the other hand, the acetylcholine of the neurohypophysis almost disappeas 2 3 hours after the stress. Acetylcholine is demonstrated in the hypothalamus until the activity of cholinesterase is intensified. 
The extract of posterior pituitary

$(200 x)$
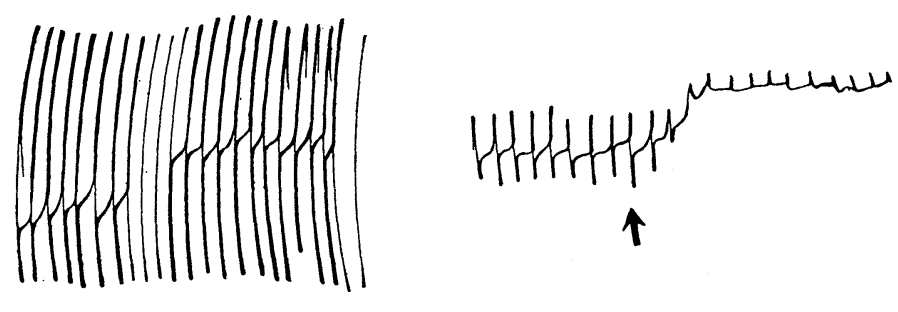

$\uparrow$

The extract of hypothalamus

$(20 x)$

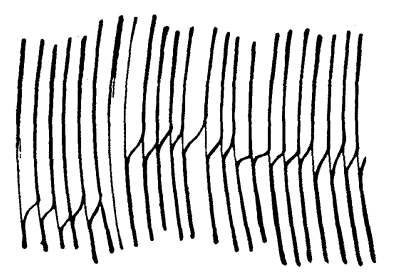

$\uparrow$

before

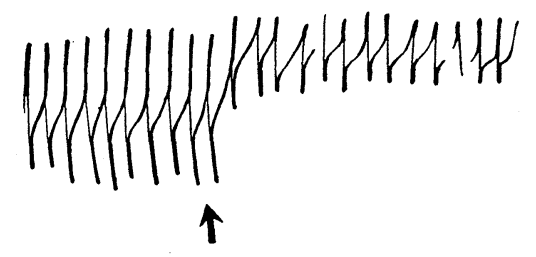

after

The release of acetylcholine (dog)

Fig. 9.

Table 5. The concentration of acetylcholine after burn

(dog)

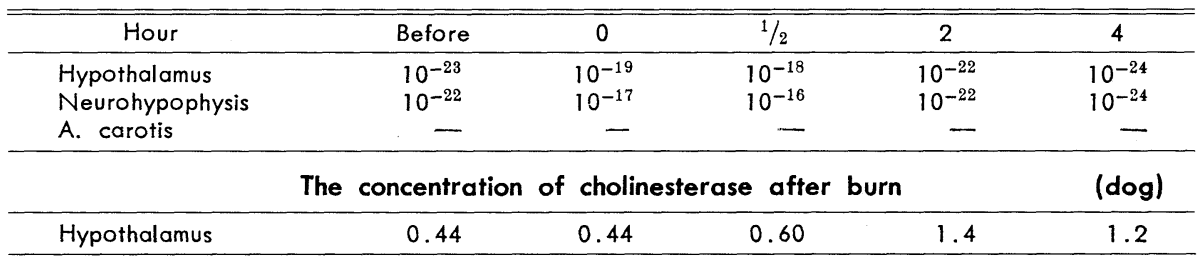

\section{DISGUSSION}

In both the human and experimental animals it is proved that during the surgical stress the neurosecretion of the hypothalamus and the posterior pituitary is markedly stimulated, since the increase of the serum ADS level, decrease of the ADS concentration in the posterior pituitary and the hypothalamus, and the reduction of Gomori's substance in the nucleus supraopticus, nucleus paraventricularis, and neurohypophysis are directly and immediately caused by the surgical stress.

Furthermore, it can be seen that the neurosecretion is stimulated by the stress from the fact that a high antidiuretic activity is found in the urinary poly- 
peptide fraction stained by ninhydrin, when the urine excreted after the stress is developed by the paper chromatography.

The secretion of ADS can be suppressed by pretreatment, such as vagotomy, adrenaline injection, and atropine injection. The action current of the vagus nerve intensifies during and immediately after the stress. Therefore, the stimulus to secrete $\mathrm{ADH}$ might be transmitted through the parasympathetic nerves after the irritation of the vagus nerve by the surgical stress.

On the other hand, acetylcholine is found in the posterior pituitary immediately after the stress, but at the same period the serum ADS level of the systemic circulation is not elevated and acetylcholine is not found in the blood and hypothalamus. Accordingly, neurosecretion is not accelerated simply by the discharge of the acetylcholine in the neurohypophysis. The ADH secretion begins only after the acetylcholine reaches the hypothalamus a few minutes after the stress. Acetylcholine cannot be found in the hypothalamus immediately after the stress.

\section{SUMMARY}

1) Adult female mongrel dogs were employed as subjects. These experimental animals were divided into four groups: Untreated, adrenaline injected, atropine injected, and vagotomy group. Each group was given the same surgical stress.

2) In the untreated group, neurosecretion was found to be remarkable after the stress.

3) In the adrenaline and atropine injected group, and the vagotomy group, neurosecretion by the stress was suppressed.

4) Action current of the vagus nerve showed that the parasympathetic nerves are markedly stimulated by the stress.

5) Acetylcholine is discharged by the stress in the neurohypophysis at first, and later appears in the hypothalamus.

6) According to these findings, it is concluded that the vagus nerve is stimulated by the surgical stress, then acetylcholine is liberated in the neurohypophysis, and thereafter in the hypothalamus. Neurosecretion follows thereon.

\section{REFERENCES}

1. Allen, L.: Biochem. J. 34: 858, 1940.

2. Bargmann, W.: Ztsch. Zellforsch. 34: 610, 1949.

3. Heller, H.: J. Pharmacy \& Pharmacol., 3: 619, 1951.

4. Inou, T.: Tokyo J. Med. Sci. 59: 295, 1953.

5. Larson, E.: J. Pharmacol. Exp. Therap. 62: 346, 1938.

6. Lloyd, C.W. and J. Lobotsky: J. Clin. Endocrinol. 10 : 318, 1950.

7. O'Conner, W.J.: Biol. Rev. 22: 30, 1947.

8. Pickford, M. and J.A. Watt: J. Physiol. 114: 333, 1951.

10. Shibusawa. K. and T. Inou: Rinsho Geka 6: 505, 1951. (In Japanese)

11. Shibusawa. K., T. Inou and T. Itou: Trans. Conf. Endocrinol. Tokyo Univ. 2: 208, 1952.

12. Shibusawa, K., T. Inou and S. Osono: Trans. Cont. Endocrinol. Tokyo Univ. 4 : $83,1953$. 
13. Shibusawa, K., T. Inou, S. Osono, K. Yosimura and T. Itou: Sogo Rinsho 10: 304, 1953. (In Japanese)

14. Shibusawa. K.: Naibunpi (In press)

15. Vigneaud, V. Du., C. Ressler, J.M. Swan, C.W. Roberts, P.G. Katsoyannis and S. Gordon: J. Am. Chem.. Soc. 75: 4879, 1953. 